\title{
THE EFFECT OF NOR-EPINEPHRINE ON THE ELECTROLYTE COMPOSITION OF ARTERIAL SMOOTH MUSCLE ${ }^{1}$
}

\author{
By LOUIS TOBIAN ${ }^{2}$ AND ADACIE FOX \\ (From the Departments of Pharmacology and Internal Medicine, Southwestern Medical School, \\ The University of Texas, Dallas, Texas)
}

(Submitted for publication September 28, 1955 ; accepted November 23, 1955)

The changes in the electrolyte composition of arterial wall in renal and desoxycorticosterone induced hypertension (1) have stimulated us to investigate the changes in the electrolytes of arterial smooth muscle that occur when an artery is brought under the influence of nor-epinephrine. The effects of this particular substance are especially important since present evidence indicates that it is the main sympathetic neurohumoral agent affecting the peripheral arterial system. This study was first attempted with arterial rings in vitro using the Krebs-Henseleit medium. In this medium the control arteries lost large amounts of potassium, a situation which prompted an in vivo approach.

\section{METHODS}

All dogs were given a standard dose of Nembutal for anesthesia. The carotid was cannulated in each dog to provide a continuous recording of arterial blood pressure.

In 12 dogs, the right femoral artery was ligated and quickly excised, stripped of adventitia, blotted free of blood, and placed in a polyethylene weighing bottle for analysis. As soon as the right femoral artery had been excised, an infusion of nor-epinephrine in saline (16 micrograms per cc.) was begun. The infusion lasted 30 minutes, and the rate of the infusion was adjusted to maintain a $100 \mathrm{~mm}$. $\mathrm{Hg}$ rise of arterial blood pressure. During the last 5 minutes of the 30 -minute infusion, the left femoral artery was quickly excised and treated as described above. Blood samples were drawn at the same time that each femoral artery was excised.

In five control dogs, the same procedure was employed except that there was no nor-epinephrine in the infused saline solution. The saline was given to the control dogs at the same rate as it had been infused into the "norepinephrine" dogs.

1 This investigation was supported by grants-in-aid from the American Heart Association and from the National Heart Institute of the National Institutes of Health, U.S.P.H.S.

2 Established Investigator of the American Heart Association. Present Address: Dept. of Medicine, University of Minnesota School of Medicine.
This experimental plan allows a comparison of one artery obtained before the infusion with the contralateral artery obtained during the last 5 minutes of a 30 -minute infusion. In order to determine whether the sequence of obtaining the arteries affected the results, two dogs were subjected to a "reverse" experiment, the nor-epinephrine infusion was started before any artery had been excised. The first femoral artery was obtained during the last 5 minutes of this 30 -minute nor-epinephrine infusion. Then the infusion was stopped and the dog was allowed to recover for 45 minutes. After this period of recovery, the other femoral artery was excised and prepared for analysis.

The samples of arterial wall were weighed and then frozen and dried in vacuo to a constant weight. After drying they were reweighed to determine the water content as well as the dry weight. The dry arteries were then extracted with known volumes of $.75 \mathrm{~N} \mathrm{HNO}_{3}$ (2) for 5 days. Aliquots of this extract were analyzed for sodium and potassium by flame photometry. Chloride was analyzed by Lowry's new micromethod (3). All analyses of arterial wall are expressed in terms of $100 \mathrm{gm}$. of dry solids.

\section{RESULTS}

In the group of dogs receiving nor-epinephrine it can be seen from Table I that the average potassium content of the arterial wall before the infusion was $8.1 \mathrm{mEq}$. per $100 \mathrm{gm}$. of artery solids. The average potassium content during the last 5 minutes of the infusion was $5.9 \mathrm{mEq}$. per $100 \mathrm{gm}$. solids. This average decrease of $2.2 \mathrm{mEq}$. per 100 gm. solids represents a loss of 27.5 per cent of the initial potassium content of the arteries. Every one of the dogs receiving nor-epinephrine showed a drop in the potassium content of arterial wall during the nor-epinephrine infusion. However, the per cent decrease from pre-infusion levels varied considerably from dog to dog. The smallest drop was 4 per cent, the greatest fall was 59 per cent. In this case, it is remarkable that $3 / 5$ of the total potassium was lost from the artery during the nor-epinephrine infusion.

Table II shows the potassium content of the femoral artery wall in the control dogs receiving a 
TABLE 1

The content of potassium and sodium in artery wall, before and during an infusion of nor-epinephrine ( $m E q$. per $100 \mathrm{gm}$. of artery solids)

\begin{tabular}{|c|c|c|c|c|c|c|c|}
\hline $\begin{array}{l}\text { Dog } \\
\text { No. }\end{array}$ & $\begin{array}{c}\text { K content } \\
\text { before } \\
\text { infusion }\end{array}$ & $\begin{array}{l}\mathrm{K} \text { content } \\
\text { during } \\
\text { infusion }\end{array}$ & Difference & $\%$ Change & $\begin{array}{l}\text { Na content } \\
\text { before } \\
\text { infusion }\end{array}$ & $\begin{array}{l}\text { Na content } \\
\text { during } \\
\text { infusion }\end{array}$ & Difference \\
\hline 1 & 7.0 & 2.9 & -4.1 & -59 & 18.7 & 20.3 & +1.6 \\
\hline 2 & 8.4 & 4.6 & -3.8 & -45 & 17.6 & 22.7 & $\begin{array}{r}+5.1 \\
\end{array}$ \\
\hline 3 & 9.1 & 5.1 & -4.0 & -44 & 18.2 & 21.1 & +2.9 \\
\hline 4 & 9.3 & 6.0 & -3.3 & -35 & 22.4 & 21.6 & -0.8 \\
\hline 5 & 8.3 & 5.4 & -2.9 & -35 & 19.8 & 22.4 & +2.6 \\
\hline 6 & 7.7 & 5.1 & -2.6 & -33 & 21.2 & 20.3 & -0.9 \\
\hline 7 & 8.7 & 6.7 & -2.0 & -22 & 19.6 & 22.8 & +3.2 \\
\hline 8 & 8.0 & 6.8 & -1.2 & -16 & 16.0 & 18.8 & +2.8 \\
\hline 9 & 5.0 & 4.3 & -0.7 & -13 & 21.6 & 24.4 & +2.8 \\
\hline 10 & 8.7 & 7.6 & -1.1 & -13 & 20.1 & 20.5 & +0.4 \\
\hline 11 & 8.9 & 8.1 & -0.8 & -9 & 23.7 & 23.8 & +0.1 \\
\hline 12 & 8.5 & 8.2 & -0.3 & -4 & 21.4 & 21.4 & 0 \\
\hline Average values & 8.1 & 5.9 & -2.2 & -28 & 20.0 & 21.7 & +1.7 \\
\hline
\end{tabular}

saline infusion without nor-epinephrine. Instead of showing a decrease in the potassium content of arterial wall during the infusion, these dogs had an average 17 per cent increase in potassium content during the infusion. Four of the five dogs showed a gain of potassium in the arterial wall during the saline infusion. One dog had a 10 per cent decrease of potassium in the arterial wall during the saline infusion. The dogs receiving nor-epinephrine lost an average of $2.2 \mathrm{mEq}$. of potassium per $100 \mathrm{gm}$. of artery solids; the dogs receiving saline averaged a $1.1 \mathrm{mEq}$. gain in potassium in the arterial wall. This difference is highly significant statistically with a $\mathrm{p}$ value of less than .001 .

Tables I and II also show the changes in sodium in arterial wall after the various infusions. The dogs receiving nor-epinephrine gained an average of $1.7 \mathrm{mEq}$. of sodium per $100 \mathrm{gm}$. of artery solids. This is to be compared with a loss of $2.2 \mathrm{mEq}$. of potassium in these same arteries. The gain in sodium in arterial wall covers only about $3 / 4$ of the loss of potassium. The dogs receiving saline without nor-epinephrine lost on the average $0.4 \mathrm{mEq}$. of sodium from the arterial wall during the infusion. Here again we have opposite responses in the series of dogs receiving nor-epinephrine and in the control series receiving saline. The series receiving nor-epinephrine shows an average gain in sodium in the arterial wall; the saline series shows a loss of sodium from the artery. The difference between these groups appears to be statistically significant with a p value of .03 .

In the series of dogs receiving nor-epinephrine, even though the loss of potassium from the arterial wall was accompanied by an average gain in sodium, the responses in the individual dogs were highly variable. In general the responses could be divided into three types.

The first type represents cases where the decrease of potassium in the artery after nor-epinephrine was fairly well balanced by an increase in sodium. Dogs No. 3 and 5 exemplify this type of response.

TABLE II

The content of potassium and sodium in artery wall before and during an infusion of saline ( $m E q$. per $100 \mathrm{gm}$. of artery solids)

\begin{tabular}{|c|c|c|c|c|c|c|c|}
\hline $\begin{array}{l}\text { Dog } \\
\text { No. }\end{array}$ & $\begin{array}{c}\mathrm{K} \text { content } \\
\text { before } \\
\text { infusion }\end{array}$ & $\begin{array}{c}\mathrm{K} \text { content } \\
\text { during } \\
\text { infusion }\end{array}$ & Difference & $\%$ Change & $\begin{array}{c}\text { Na content } \\
\text { before } \\
\text { infusion }\end{array}$ & $\begin{array}{c}\text { Na content } \\
\text { during } \\
\text { infusion }\end{array}$ & Difference \\
\hline $\begin{array}{l}13 \\
14 \\
15 \\
16 \\
17\end{array}$ & $\begin{array}{l}5.6 \\
6.8 \\
8.2 \\
7.1 \\
8.6\end{array}$ & $\begin{array}{r}8.1 \\
8.5 \\
10.0 \\
7.3 \\
7.7\end{array}$ & $\begin{array}{l}+2.5 \\
+1.7 \\
+1.8 \\
+0.2 \\
-0.9\end{array}$ & $\begin{array}{l}+45 \\
+26 \\
+22 \\
+\quad 3 \\
-10\end{array}$ & $\begin{array}{l}21.0 \\
19.5 \\
22.2 \\
18.9 \\
23.4\end{array}$ & $\begin{array}{l}20.0 \\
20.6 \\
21.0 \\
19.2 \\
22.2\end{array}$ & $\begin{array}{l}-1.0 \\
+1.1 \\
-1.2 \\
+0.3 \\
-1.2\end{array}$ \\
\hline Average values & 7.2 & 8.3 & +1.1 & +17 & 21.0 & 20.6 & -0.4 \\
\hline
\end{tabular}


TABLE III

"Reverse" nor-epinephrine experiment

( $m E q$. per $100 \mathrm{gm}$. of artery solids)

\begin{tabular}{|c|c|c|c|c|c|c|c|}
\hline $\begin{array}{l}\text { Dog } \\
\text { No. }\end{array}$ & $\begin{array}{c}\text { K content } \\
\text { during } \\
\text { nor-epinephrine } \\
\text { infusion }\end{array}$ & $\begin{array}{l}\text { K content } \\
45 \text { min. } \\
\text { after } \\
\text { infusion }\end{array}$ & Difference & $\%$ Change & $\begin{array}{c}\text { Na content } \\
\text { during } \\
\text { nor-epinephrine } \\
\text { infusion }\end{array}$ & $\begin{array}{l}\text { Na content } \\
45 \text { min. } \\
\text { after } \\
\text { infusion }\end{array}$ & Difference \\
\hline $\begin{array}{l}18 \\
19\end{array}$ & $\begin{array}{l}6.8 \\
8.4\end{array}$ & $\begin{array}{r}8.9 \\
10.5\end{array}$ & $\begin{array}{l}+2.1 \\
+2.1\end{array}$ & $\begin{array}{l}+31 \\
+25\end{array}$ & $\begin{array}{l}22.4 \\
21.9\end{array}$ & $\begin{array}{l}19.8 \\
22.3\end{array}$ & $\begin{array}{r}-2.6 \\
+0.4\end{array}$ \\
\hline
\end{tabular}

There are other dogs in whom the rise in sodium in the artery significantly exceeded the decrease in potassium after nor-epinephrine. Dogs No. 2, 7,8 , and 9 are examples of this type.

However, there are six dogs that demonstrate a striking independence in the sodium and potassium changes. Dogs 4 and 6 had a decrease in potassium in the artery after nor-epinephrine and a decrease in sodium as well. Dog 12 had a small drop in potassium with no change in sodium. And dogs No. 1, 10 and 11 had very small gains in sodium in the arterial wall that only compensated for about $1 / 3$ of the loss of potassium. These examples indicate that the changes in potassium content of these artery cells are not merely a passive electrochemical consequence of variations in the activity of a hypothetical "sodium pump mechanism." It appears that in these artery cells, sodium and potassium can vary independently of one another, and each cation probably has a separate active mechanism in the cell membrane regulating its permeability and intracellular accumulation. Nor-epinephrine in certain instances can affect the potassium mechanism in the membrane while not having any influence on the sodium mechanism.

Table III shows a "reverse" nor-epinephrine experiment in two dogs. In dog No. 18 the potassium content of the arterial wall was $6.8 \mathrm{mEq}$. during the nor-epinephrine infusion and $8.9 \mathrm{mEq}$. 45 minutes after the infusion had been stopped. In $\operatorname{dog}$ No. 19 the potassium was $8.4 \mathrm{mEq}$. during the infusion and $10.5 \mathrm{mEq} .45$ minutes after the infusion. In both of these dogs the potassium content during the nor-epinephrine infusion was lower than during the recovery period when the artery was not under the influence of nor-epinephrine. In one, the potassium loss was replaced by a sodium gain. In the other, there was a loss of both potassium and sodium. The results in this "reverse" experiment agree with those outlined above.

The arteries of the dogs receiving nor-epineph- rine lost an average of $7.8 \mathrm{gm}$. of water per 100 gm. of artery solids during the nor-epinephrine infusion, while the arteries of the control series gained an average of $8.1 \mathrm{gm}$. of water during the saline infusion. This difference would not be considered statistically significant with a $\mathrm{p}$ value of 0.1 . However, the arteries lost $0.57 \mathrm{mEq}$. of total cation (sodium + potassium) per $100 \mathrm{gm}$. of solids during the nor-epinephrine infusion and gained $0.65 \mathrm{mEq}$. of total cation during the saline infusion. These changes in total cation content parallel the direction of the changes in water content.

The changes in chloride content of the artery and of the serum were not significantly different in the "nor-epinephrine" group compared to the saline control group. In dogs where the sodium in the artery increased and the chloride did not, there is circumstantial evidence that the sodium was moving into the cells.

The sera of dogs receiving nor-epinephrine lost an average of $1.2 \mathrm{mEq}$. of sodium and $0.1 \mathrm{mEq}$. of potassium per liter during the nor-epinephrine infusion. The serum of the control dogs lost an average of $1.2 \mathrm{mEq}$. of sodium and $0.5 \mathrm{mEq}$. of potassium per liter during the saline infusion. There was no significant difference between these two groups in regard to the serum changes during the infusions. The changes in the concentrations of sodium and potassium in serum were small during the infusion of nor-epinephrine. They are to be contrasted with the observations of Muirhead, Goth, and Jones who infused much greater quantities of nor-epinephrine and found a considerable decrease in sodium concentration and an increase in potassium concentration in serum during the infusion (4). They postulated that these serum changes might result from sodium entering and potassium leaving cells under the influence of norepinephrine. The findings in our study indicate that at least in arteries these shifts do occur. And with their larger doses of nor-epinephrine the ca- 
tion shifts in various tissues could have been great enough to lower serum sodium and raise serum potassium.

\section{DISCUSSION}

The results indicate that arterial wall invariably lost potassium under the influence of norepinephrine, whereas there was a variable gain in sodium to replace the lost potassium. The smooth muscle cells of the arterial wall constitute the bulk of the cells present, and it is likely that the changes in the arterial wall as a whole mainly reflect changes in this smooth muscle. These electrolyte shifts in arterial wall can best be explained by assuming that nor-epinephrine affects the membrane of the smooth muscle cells allowing for a net loss of potassium and a variable gain in sodium.

Nor-epinephrine in fairly high concentration will usually cause a contraction of arterial smooth muscle (5). It is possible that the electrolyte shifts described above play an important part in the chain of chemical events leading to the muscle contraction. The electrolyte shifts could affect the membrane potential of the cell and thus change the tension of the smooth muscle (see below). It is also well known that changes in the concentration of potassium or sodium ions profoundly affect the contractility of actomyosin, presumably by altering the electrical charges on the protein. Such an effect may be occurring in the smooth muscle cells of arteries when nor-epinephrine reduces the content of intracellular potassium.

In nerve, skeletal muscle, and heart muscle, activity or contraction is associated with a loss of intracellular potassium and a gain of intracellular sodium. Our results on arterial smooth muscle would seem to fit in with these observations. However, Daniel, working with rabbit uterine strips, has reported that a contraction of the strip caused by nor-epinephrine produces a definite loss of potassium with a decreased uptake of sodium, while a contraction of the strip caused by either acetylcholine or histamine was associated with no significant change in either potassium or sodium content (6). Hence contraction of uterine smooth muscle, at least, is not invariably associated with a drop in potassium and a gain in sodium.

Recently, Bülbring, working with a longitudinal smooth muscle of the colon, found that the tension of the muscle was always inversely related to the membrane potential, as determined by puncture with micro-electrodes $(\bar{\tau})$. This relationship held during spontaneous activity of the muscle, during the influence of drugs employed to increase tension, and during electrical stimulation of the muscle. If such a relationship were also true for arterial smooth muscle, the membrane potential during physiological contraction might be reduced because of the loss of intracellular potassium. However, this concept remains no more than speculation until some direct evidence can be obtained.

Insofar as dog arteries can be compared with rat arteries, the pattern of electrolyte change associated with nor-epinephrine is different from the pattern of electrolyte change associated with either renal or desoxycorticosterone induced hypertension. With nor-epinephrine the arterial wall loses potassium, while in renal or desoxycorticosterone hypertension the arterial wall gains potassium (1).

\section{SUMMARY}

1. Dogs were infused with either nor-epinephrine in saline or saline alone, and samples of arterial wall were obtained before and during each infusion. The samples of arterial wall were analyzed for sodium, potassium, chloride, and water.

2. Under the conditions of these experiments, the femoral artery wall in the dog invariably loses potassium when under the influence of nor-epinephrine. This loss averaged 27 per cent of the total potassium in the artery wall. One dog lost 59 per cent of the total potassium during the norepinephrine infusion. Control dogs receiving saline showed an average increase in the potassium content of the arterial wall during the saline infusion.

3. The loss of potassium from the arterial wall during a nor-epinephrine infusion was often accompanied by a gain in sodium. The average gain of sodium in the arterial wall in the group of "norepinephrine" dogs was significantly greater than that seen in the control group. However, in half the "nor-epinephrine" dogs, the loss of potassium from the arterial wall was accompanied by little or no increase in sodium. It seemed that the sodium and potassium in artery wall could vary independently under the influence of nor-epinephrine. 
4. The decrease of potassium in the arterial wall of dogs after nor-epinephrine is in contrast with the gain in potassium in the arterial wall of rats with renal or desoxycorticosterone hypertension.

5. The loss of potassium from arterial smooth muscle cells may be important in the chain of chemical events associated with a contraction of arterial smooth muscle induced by nor-epinephrine.

\section{ACKNOWLEDGMENT}

The authors are greatly indebted to Dr. Andres Goth for providing facilities, helpful advice, and continuous encouragement.

\section{REFERENCES}

1. Tobian, L., Jr., and Binion, J., Artery wall electrolytes in renal and DCA hypertension. J. Clin. Invest., 1954, 33, 1407.
2. Lowry, O. H., and Hastings, A. B., Histochemical changes associated with aging. I. Methods and calculations. J. Biol. Chem., 1942, 143, 257.

3. Lowry, O. H., Roberts, N. R., Leiner, K. Y., Wu, M.-L., and Farr, A. I., The quantitative histochemistry of brain. I. Chemical methods. J. Biol. Chem., 1954, 207, 1.

4. Muirhead, E. E., Goth, A., and Jones, F., Sodium and potassium exchanges associated with nor-epinephrine infusions. Am. J. Physiol., 1954, 179, 1.

5. Furchgott, R. F., and Bhadrakom, S., Reactions of strips of rabbit aorta to epinephrine, isopropylarterenol, sodium nitrite and other drugs. J. Pharmacol. \& Exper. Therap., 1953, 108, 129.

6. Daniel, E. E., Abstracts of Western Regional Meeting, National Research Council of Canada, 1955.

7. Bülbring, E., Correlation between membrane potential, spike discharge and tension in smooth muscle. J. Physiol., 1955, 128, 200. 